\title{
BELAJAR BERMAKNA AUSUBEL
}

\author{
Oleh: Nur Rahmah \\ Dosen Prodi Matematika STAIN Palopo
}

\begin{abstract}
Abstrak:
Pembelajaran bermakna merupakan suatu proses mengaitkan informasi baru pada konsep-konsep relevan yang terdapat dalam struktur kognitif seseorang Struktur kognitif meliputi fakta-fakta, konsep-konsep, dan generalisasi-generalisasi yang telah dipelajari dan diingat siswa. Faktorfaktor utama yang mempengaruhi belajar bermakna menurut Ausubel adalah struktur kognitif yang ada, stabilitas dan kejelasan pengetahuan dalam suatu bidang studi tertentu dan pada waktu tertentu. Pembelajaran bermakna terjadi apabila seseorang belajar dengan mengasosiasikan fenomena baru ke dalam struktur pengetahuan mereka. Dalam proses belajar seseorang mengkonstruksi apa yang telah ia pelajari dan mengasosiasikan pengalaman, fenomena, dan fakta-fakta baru ke dalam struktur pengetahuan mereka.
\end{abstract}

Kata Kunci: Belajar bermakna, Ausubel

\section{Pendahuluan}

Menurut Ausubel (Burhanuddin, 1996:116) faktor utama yang mempengaruhi belajar bermakna adalah struktur kognitif yang telah ada, stabilitas dan kejelasan pengetahuan dalam sutu bidang studi dan pada waktu tertentu. Sifat-sifat struktur kognitif menentukan validitas dan kejelasan arti-arti yang timbul pada waktu informasi baru masuk ke dalam struktur kognitif itu, demikian pula sifat proses interaksi yang terjadi. Ausubel menolak pendapat bahwa semua kegiatan belajar dengan menemukan adalah bermakna, sedangkan kegiatan dengan ceramah adalah kurang bermakna. Belajar ini perlu bila seseorang memperoleh informasi baru dalam dunia pengetahuan yang sama sekali tidak berhubungan dengan apa yang telah ia ketahui.

Menurut Ausubel dan Novak (Burhanuddin, 1996: 115) ada tiga kebaikan belajar bermakna, yaitu:

1) Informasi yang dipelajari secara bermakna lebih lama diingat 
2) Informasi baru yang telah dikaitkan dengan konsep-konsep relevan sebelumnya dapat meningkatkan konsep yang telah dikuasai sebelumnya sehingga memudahkan proses belajar mengajar berikutnya untuk memberi pelajaran yang mirip

3) Informasi yang pernah dilupakan setelah pernah dikuasai sebelumnya masih meninggalkan bekas sehingga memudahkan proses belajar mengajar untuk materi pelajaran yang mirip walaupun telah lupa.

\section{Pembahasan}

A. Teori Belajar Bermakna Ausubel

David Ausubel adalah seorang ahli psikologi pendidikan yang terkenal dengan teori belajar bermakna (meaningfull). Ausubel membedakan antara belajar menemukan dengan belajar menerima. Pada belajar menerima siswa hanya menerima, jadi tinggal menghafalkannya, tetapi pada belajar menemukan konsep ditemukan oleh siswa, jadi tidak menerima pelajaran begitu saja.

Menurut Ausubel (Burhanuddin, 1996 : 112) pembelajaran bermakna merupakan suatu proses mengaitkan informasi baru pada konsep-konsep relevan yang terdapat dalam struktur kognitif seseorang. Struktur kognitif meliputi fakta-fakta, konsep-konsep, dan generalisasi-generalisasi yang telah dipelajari dan diingat siswa.

Faktor-faktor utama yang mempengaruhi belajar bermakna menurut Ausubel adalah struktur kognitif yang ada, stabilitas dan kejelasan pengetahuan dalam suatu bidang studi tertentu dan pada waktu tertentu. Pembelajaran bermakna terjadi apabila seseorang belajar dengan mengasosiasikan fenomena baru ke dalam struktur pengetahuan mereka. Dalam proses belajar seseorang mengkonstruksi apa yang telah ia pelajari dan mengasosiasikan pengalaman, fenomena, dan fakta-fakta baru ke dalam struktur pengetahuan mereka. 
B. Tipe Belajar Menurut Ausubel

Ada beberapa tipe belajar menurut Ausubel, yaitu:

1. Belajar dengan penemuan yang bermakna yaitu mengaitkan pengetahuan yang telah dimilikinya dengan materi pelajaran yang dipelajari itu. Atau sebaliknya, siswa terlebih dahulu menemukan pengetahuannya dari apa yang ia pelajari kemudian pengetahuan baru tersebut ia kaitkan dengan pengetahuan yang sudah ada.

2. Belajar dengan penemuan yang tidak bermakna yaitu pelajaran yang dipelajari ditemukan sendiri oleh siswa tanpa mengaitkan pengetahuan yang telah dimilikinya, kemudian dia hafalkan.

3. Belajar menerima (ekspositori) yang bermakna yaitu materi pelajaran yang telah tersusun secara logis disampaikan kepada siswa sampai bentuk akhir, kemudian pengetahuan yang baru ia peroleh itu dikaitkan dengan pengetahuan lain yang telah dimiliki.

C. Kebaikan Belajar Bermakna

Menurut Ausubel dan Novak (Burhanuddin, 1996 : 115) ada tiga kebaikan belajar bermakna, yaitu :

1. Informasi yang dipelajari secara bermakna lebih lama diingat.

2. Informasi baru yang telah dikaitkan dengan konsep-konsep relevan sebelumnya dapat meningkatkan konsep yang telah dikuasai sebelumnya sehingga memudahkan proses belajar mengajar berikutnya untuk memberi pelajaran yang mirip.

3. Informasi yang pernah dilupakan setelah pernah dikuasai sebelumnya masih meninggalkan bekas sehingga memudahkan proses belajar mengajar untuk materi pelajaran yang mirip walaupun telah lupa.

Prasyarat agar belajar menerima menjadi bermakna menurut Ausubel, yaitu:

1. Belajar menerima yang bermakna hanya akan terjadi apabila siswa memiliki strategi belajar bermakna,

2. Tugas-tugas belajar yang diberikan kepada siswa harus sesuai dengan pengetahuan yang telah dimiliki siswa.

3. Tugas-tugas belajar yang diberikan harus sesuai dengan tahap perkembangan intelektual siswa. 
D. Hubungan Teori Belajar Bermakna dan Konstruktivisme

Teori Belajar Bermakna Ausubel sangat dekat dengan Konstruktivisme. Keduanya menekankan pentingnya pelajar mengasosiasikan pengalaman, fenomena, dan fakta-fakta baru kedalam sistem pengertian yang telah dipunyai. Keduanya menekankan pentingnya asimilasi pengalaman baru kedalam konsep atau pengertian yang sudah dipunyai siswa. Keduanya mengandaikan bahwa dalam proses belajar itu siswa aktif.

Ausubel berpendapat bahwa guru harus dapat mengembangkan potensi kognitif siswa melalui proses belajar yang bermakna. Sama seperti Bruner dan Gagne, Ausubel beranggapan bahwa aktivitas belajar siswa, terutama mereka yang berada di tingkat pendidikan dasar, akan bermanfaat kalau mereka banyak dilibatkan dalam kegiatan langsung. Namun untuk siswa pada tingkat pendidikan lebih tinggi, maka kegiatan langsung akan menyita banyak waktu. Untuk mereka, menurut Ausubel, lebih efektif kalau guru menggunakan penjelasan, peta konsep, demonstrasi, diagram, dan ilustrasi.

E. Langkah-langkah Belajar Bermakna Menurut Ausubel

Cara Pembelajaran Bermakna dengan Menggunakan Peta Konsep :

1) Pilih suatu bacaan dari buku pelajaran.

2) Tentukan konsep-konsep yang relevan.

3) Urutkan konsep-konsep dari yang paling inklusif ke yang paling tidak inklusif atau contoh-contoh.

4) Susun konsep-konsep tersebut di atas kertas mulai dari konsep yang paling inklusif di puncak konsep ke konsep yang tidak inklusif di bawah.

5) Hubungkan konsep-konsep ini dengan kata-kata penghubung sehingga menjadi sebuah peta konsep.

6) Langkah-langkah yang dilakukan guru untuk menerapkan belajar bermakna Ausubel adalah sebagai berikut: Advance organizer, Progressive differensial, integrative reconciliation, dan consolidation. 
Advance organizer merupakan pola interaksi siswa dengan guru di dalam kelas yang menyengkut strategi, pendekatan, metode, dan teknik pembelajaran yang diterapkan dalam pelaksanaan kegiatan belajar mengajar di kelas (Suherman, 2001: 8). Model pembelajaran disusun untuk mengarahkan belajar, dimana guru membantu siswa untuk memperoleh informasi, ide keterampilan, nilai, cara berpikir dan mengekspresikan dirinya (Joyce et.al dalam Budiningsih, 2003 : 11).

Langkah-langkah Belajar Bermakna Menurut Ausubel :

1) Menentukan tujuan pembelajaran.

2) Melakukan identifikasi karakteristik siswa (kemampuan awal, motivasi, gaya belajar, dan sebagainya).

3) Memilih materi pelajaran sesuai dengan karakteristik siswa dan mengaturnya dalam bentuk konsep-konsep inti.

4) Menentukan topik-topik dan menampilkannya dalam bentuk advance organizer yang akan dipelajari siswa.

5) Mempelajari konsep-konsep inti tersebut, dan menerapkannya dalam bentuk nyata/konkret.

6) Melakukan penilaian proses dan hasil belajar siswa.

\section{Penutup}

Berdasarkan pembahasan yang telah diuraikan, maka ada beberapa kebaikan belajar bermakna (meaningful learning), yaitu:

1. Informasi yang dipelajari secara bermakna lebih lama diingat

2. Informasi baru yang telah dikaitkan dengan konsep-konsep relevan sebelumnya dapat meningkatkan konsep yang telah dikuasai sebelumnya sehingga memudahkan proses belajar mengajar berikutnya untuk memberi pelajaran yang mirip

3. Informasi yang pernah dilupakan setelah pernah dikuasai sebelumnya masih meninggalkan bekas sehingga memudahkan proses belajar mengajar untuk materi pelajaran yang mirip walaupun telah lupa.

4. Faktor-faktor utama yang mempengaruhi belajar bermakna menurut Ausubel adalah struktur kognitif yang ada, stabilitas dan 
kejelasan pengetahuan dalam suatu bidang studi tertentu dan pada waktu tertentu. Pembelajaran bermakna terjadi apabila seseorang belajar dengan mengasosiasikan fenomena baru ke dalam struktur pengetahuan mereka. Dalam proses belajar seseorang mengkonstruksi apa yang telah ia pelajari dan mengasosiasikan pengalaman, fenomena, dan fakta-fakta baru ke dalam struktur pengetahuan mereka.

Kemudian yang termasuk ke dalam langkah-langkah Belajar Bermakna Menurut Ausubel :

1. Menentukan tujuan pembelajaran.

2. Melakukan identifikasi karakteristik siswa (kemampuan awal, motivasi, gaya belajar, dan sebagainya).

3. Memilih materi pelajaran sesuai dengan karakteristik siswa dan mengaturnya dalam bentuk konsep-konsep inti.

4. Menentukan topik-topik dan menampilkannya dalam bentuk advance organizer yang akan dipelajari siswa.

5. Mempelajari konsep-konsep inti tersebut, dan menerapkannya dalam bentuk nyata/konkret.

6. Melakukan penilaian proses dan hasil belajar siswa.

\section{Daftar Pustaka}

Anak Ciremai. 2011. Pengertian Belajar Bermakna. (Online):http://www.anakciremai.com/2011/11/pengertianbelajar-bermakna.html, diakses tanggal 9 Maret 2012).

Budiningsih, A. 2005. Belajar dan Pembelajaran. PT Rinerka Cipta : Jakarta.

Burhanuddin; Nur Wahyuni, Esa. 2010. Teori Belajar dan Pembelajaran. Jogjakarta: Penerbit Ar-Ruzz Media.

Dina Octaria. Teori Belajar Bermakna dari David P Ausubel. http://dinaoctaria.wordpress.com/2012/10/15/teori-belajarbermakna-dari-david-p-ausubel/. Online 19 feb 2013.

Mardhiyanti, D. 2010. Teori Belajar Bermakna dari David P. Ausubel.(Online)

http://mardhiyanti.blogspot.com/2010/03/teori-belajarbermakna-dari-david-p.html, diakses 9 maret 2012).

Suherman. 2000. Buku Saku Perkembangan Anak. Jakarta: EGC. 